\title{
Carcass and Non-carcass Components of Priangan and Javanese Fat-tailed Rams Slaughtered at Mature Live Weight
}

\author{
M. Baihaqi* \& R. Herman \\ Department of Animal Production and Technology, Faculty of Animal Science, Bogor Agricultural University \\ Jln. Agatis, Kampus IPB Darmaga Bogor 16680 West Java, Indonesia \\ (Received 31-10-2012; Reviewed 16-12-2012; Accepted 31-01-2013)
}

\begin{abstract}
Twenty-three of indigenous Priangan and Javanese Fat-tailed (JFT) ram breeds were used to evaluate its carcass and non carcass components slaughtered at mature live weight. Five Priangan rams and six JFT rams were slaughtered at $32.5 \mathrm{~kg}$ of live weight while six other rams of each breeds were also slaughtered at $40 \mathrm{~kg}$ of live weight. Before the rams were slaughtered, they were fattened using pellet ration which was formulated according to NRC for fattening $10 \mathrm{~kg}$ of lamb, containing $73.3 \%$ TDN and $16 \%$ protein in dry matter bases. Feed and water were given ad libitum. Rams were slaughtered and dissected when they reached their assigned slaughter weight ( 32.5 and $40 \mathrm{~kg})$. The results showed that both breeds had high percentage of carcass (53\%-55\%) with no significantly different between breeds $(P>0.05)$ either were slaughtered at $32.5 \mathrm{~kg}$ or $40 \mathrm{~kg}$. However, carcass of Priangan rams had significantly more muscle, but less fat than Javanese Fat-tailed rams at mature live weight $(\mathrm{P}<0.05)$. Non-carcass components were not significantly different between breeds $(\mathrm{P}>0.05)$ except for head, tail and testes $(\mathrm{P}<0.01)$ and liver $(\mathrm{P}<0.05)$. The edible and inedible portion of non-carcass ranged from $30 \%-32 \%$ and $12 \%-15 \%$ of slaughter weight, respectively.
\end{abstract}

Key words: Priangan, Javanese Fat-tailed Sheep, carcass, non-carcass, mature live weight

\section{ABSTRAK}

Dua puluh tiga domba jantan Priangan dan Ekor Gemuk (DEG) digunakan pada penelitian ini untuk mengevaluasi komposisi karkas dan non karkasnya pada bobot dewasa tubuh. Masingmasing enam domba Priangan dan DEG disembelih ketika mempunyai bobot $40 \mathrm{~kg}$, sementara lima ekor domba Priangan dan enam ekor DEG disembelih ketika mempunyai bobot $32,5 \mathrm{~kg}$. Sebelum disembelih, domba digemukkan menggunakan pakan berbentuk pellet yang mengandung $73,3 \%$ TDN dan $16 \%$ protein. Domba kemudian dipotong ketika memasuki bobot hidup $32,5 \mathrm{~kg}$ dan 40 kg. Komponen non karkas diukur untuk mengetahui edible portion dari masing-masing bangsa domba. Hasil penelitian menunjukkan bahwa kedua bangsa domba tidak menunjukkan perbedaan yang nyata dengan persentase karkas yang tinggi (53\%-55\%). Meskipun demikian, domba Priangan mempunyai komposisi daging yang signifikan lebih tinggi dan lemak yang lebih rendah daripada DEG $(P<0,05)$. Komponen non-karkas tidak menunjukkan perbedaan antar kedua bangsa domba kecuali kepala, ekor dan testis $(\mathrm{P}<0,01)$ dan hati $(\mathrm{P}<0,05)$. Edible portion dan inedible portion nonkarkas masing-masing mencapai $30 \%-32 \%$ dan $12 \%-15 \%$ dari bobot potong domba.

Kata kunci: priangan, domba ekor gemuk, karkas, non-karkas, dewasa tubuh

\section{INTRODUCTION}

Sheep is one of the important livestock commodities in Indonesia, playing an important role in the context of agriculture. Although the consumption of sheep meat is still low compared to chicken and beef, but the annual

*Corresponding author:

e-mail: baihaqi@ipb.ac.id growth of the sheep population from 2005 to 2010 had been increasing at $4.9 \%$ with a population of 8.3 to 10.7 millions. Most of the sheep population is in Java Island $(92.7 \%)$ spread in West Java (58.5\%), Central Java $(20.0 \%)$ and East Java (7.0\%) (DGLAH, 2011).

Non-carcass components generally are considered as by-product in slaughtering process. However, the economic value of non-carcass is enough to cover the cost during slaughter (da Silva et al., 2011). Moreover, leather is a non-carcass component that has high eco- 
nomical value as a primary source of profit for sheep butcher (Herman, 2005). Offals are favorite food in some countries including in Indonesia.

Carcass and non-carcass characteristics are affected by live weight of mature sheep (Lambe et al., 2007), slaughter weight (Pena et al., 2005) and sheep breeds (Yilmaz et al., 2009). A study conducted by Herman (2005) reported that 17.5 and $25 \mathrm{~kg}$ of Priangan sheep and Javanese Fat-tailed sheep significantly different on non-carcass components between breeds particularly of head and tail. Unfortunately, characteristic data of carcass and non-carcass components of these breeds on mature live weight are rarely found. Whereas, identification of carcass and non-carcass components at optimal live weight between breeds is needed to obtain the genetic potential for edible portion production of sheep. The objective of this study was to evaluate the different characteristic of carcass and non-carcass components between Priangan and Javanese Fat-Tailed rams breeds slaughtered at mature live weight.

\section{MATERIALS AND METHODS}

\section{Animals and Fattening Procedure}

The study was conducted using a total of twentythree male lambs from two breeds, Priangan (11 heads) and Javanese Fat-tailed rams (12 heads). The animals were selected from farmers with average live weight of $10 \mathrm{~kg}$. Priangan were collected from Garut Regency, West Java, while Javanese Fat-tailed were collected from Central Java. Each of animals remained in individual indoors cage for fattening process.

Lambs were fattened using pellet ration formulated according to NRC (1985) for fattening $10 \mathrm{~kg}$ of lambs, containing $73.3 \%$ TDN and $16 \%$ protein in dry matter. Feed and water were given ad libitum. The daily body weight gain of Priangan sheep and Javanese Fat-tailed rams were 123 and $144 \mathrm{~g}$, respectively. Animals were weighed once a month. After they reached the live weight 33.9, 33.8, and 38.9; $39.8 \mathrm{~kg}$, respectively for Priangan sheep and Javanese Fat-tailed rams, then fasted for $24 \mathrm{~h}$ (water was allowed). Fasted rams of each breed were weighed at average of 32.6 and $32.5 \mathrm{~kg}$ as slaughter weight 32.5 while at average of 36.8 and 38.3 $\mathrm{kg}$ as slaughter weight $40 \mathrm{~kg}$, respectively. Rams were slaughtered when they reached their assigned slaughter weight (32.5 and $40 \mathrm{~kg})$.

\section{Slaughtering Procedure and Parameters Measurement}

Slaughtering was done according to standard halal methods at a slaughter house plant in Laboratory of Small Ruminant, Department of Animal Production and Technology, Faculty of Animal Science, Bogor Agricultural University. Blood was collected, weighed and recorded as blood weight. After the animal was skinned, the other parts of the body were weighed in hot condition before its chilled. Carcass was weighed and recorded as hot carcass weights. Dressing percentage was calculated from slaughter weight. After carcasses were chilled at $5{ }^{\circ} \mathrm{C}$ for $24 \mathrm{~h}$, carcass was split along vertebral column in two half. The left side was dissected and recorded for carcass tissue (muscle, fat and bone). The weight of the gastro-intestinal tract contents was estimated by subtracting the weight of the empty digestive tract from the weight of full gastro-intestinal tract. Empty body weight was calculated by subtracting the weight of gastro-intestinal contents from slaughter weight. The weight of the head, skin, liver, spleen, lungs (including trachea), heart, genitals, testes, kidney, pancreatic, stomach, small intestine, large intestine, tail, feet (cut at tarsal-metatarsal and carpal-metacarpal articulations), omental fat and fat-thorax each weighed as edible portion of non-carcass components. Inedible portion was calculated by sum up weight of blood and gastro-intestinal tract contents.

\section{Statistical Analyses}

Data of carcass and each parts of non-carcass were expressed in average values and standard deviation (SD) in weight (g) and percent (\%) of slaughter weight. In order to determine the differences of carcass and non carcass components between breeds (Priangan and Javanese Fat-tailed Sheep), the data were analyzed by t-test (Steel \& Torrie, 1980).

\section{RESULTS AND DISCUSSION}

\section{Carcas Performance}

Dissection processes of animals were done precisely, with the total weight percentage value after the dissection were $97.34 \%$ and $96.69 \%$ of slaughter weight, or there were decreased of $2.66 \%$ and $3.3 \%$ of slaughter weight for Priangan and Javanese Fat-tailed rams slaughtered at weight $32.5 \mathrm{~kg}$, respectively. The total weight percentage values of slaughter weight $40 \mathrm{~kg}$ were $96.57 \%$ and $98.49 \%$ or decreased of $3.43 \%$ and $1.51 \%$, respectively.

There were no significant differences of slaughter weight between Priangan and Javanese Fat-tailed rams either at slaughter weight 32.5 or $40 \mathrm{~kg}(\mathrm{P}>0.05)$ (Table 1). Likewise, carcass weight between the two breeds had similar percentage of the carcass (53.58\%-55.58\%). Live weight, carcass weight and dressing percentage were intercorrelated. Pena et al. (2005) mentioned that dressing percentage has positive correlation to slaughter weight. The slaughter process at present study was conducted at the same body weight between breeds, therefore it resulted no differences of carcass weight and dressing percentage. It indicates that at mature live weight, Priangan and Javanese Fat-tailed rams produced a similar carcass quantity, although the carcass tissue components of each breeds could be different which shows the carcass quality.

Dressing percentage of Priangan rams in this study was higher compare to that reported by Zubir et al. (2011) that was $46.09 \%$ of carcass from Priangan's slaughter weight. Study conducted by Rianto et al. (2006) resulted percentage of hot carcass of Thin-tail sheep was 
Table 1. Carcass performance of Priangan and Javanese Fat-tailed rams in slaughter weight $32.5 \mathrm{~kg}$ and $40 \mathrm{~kg}$

\begin{tabular}{|c|c|c|c|c|c|c|}
\hline \multirow{3}{*}{$\begin{array}{l}\text { Carcass performance } \\
\text { Slaughter weight (g) }\end{array}$} & \multicolumn{3}{|c|}{ Slaughter weight (32.5 kg) } & \multicolumn{3}{|c|}{ Slaughter weight $(40 \mathrm{~kg})$} \\
\hline & Priangan & JFT & \multirow{2}{*}{$\frac{\text { Sig. }}{\text { ns }}$} & Priangan & JFT & \multirow{2}{*}{$\frac{\text { Sig. }}{\text { ns }}$} \\
\hline & $32,460 \pm 55$ & $32,483 \pm 75$ & & $36,708 \pm 3,088$ & $38,292 \quad \pm 2,375$ & \\
\hline Empty body weight (g) & $29,339 \pm 95$ & $28,873 \pm 63$ & ns & $33,910 \pm 2,571$ & $35,285 \pm 1385$ & ns \\
\hline Hot carcass weight (g) & $17,380 \pm 228$ & $17,683 \pm 673$ & ns & $20,142 \pm 1,716$ & $21,258 \pm 967$ & ns \\
\hline Dressing percentage $(\%)$ & $53.6 \pm \quad 0.7$ & $55.4 \pm \quad 2.1$ & ns & $54.9 \pm$ & $55.6 \pm \quad 1.4$ & ns \\
\hline Muscle (g) & $4,849 \pm 68$ & $4,493 \pm 170$ & * & $5,701 \pm 475$ & $5,031 \pm 224$ & $*$ \\
\hline Fat $(g)$ & $2,277 \pm 31$ & $2,727 \pm 104$ & ns & $2,656 \pm 224$ & $3,696 \pm 167$ & $*$ \\
\hline Bone $(\mathrm{g})$ & $1,261 \pm 16$ & $1,162 \pm 38$ & * & $1,369 \pm 114$ & $1,317 \pm 54$ & ns \\
\hline
\end{tabular}

Note: JFT= Javanese Fat-tailed Sheep, Sig. $=$ significance differ between breeds, ${ }^{*}=$ significant differ $(\mathrm{P}<0.05)$, ns= not significant differ $(\mathrm{P}>0.05)$.

lower at $39.06 \%$, it could be caused by slaughter weight of their study was lower at $25.45 \mathrm{~kg}$, while the percentages of fats, meat and bone of carcass were $9.71 \%$, $69.03 \%$, and $21.27 \%$, respectively. Kheri sheep which have almost a similar phenotypic with Priangan sheep that was maintained intensively also produced percentage of carcass at 57\% (Karim et al., 2007).
However, this study showed that at a similar slaughter live weight, muscle tissue weight of Priangan rams was significantly higher from Javanese Fat-tailed rams for both different weights $(\mathrm{P}<0.05)$. Sheep breeds affect the amount of muscle tissue (Yilmaz et al., 2009). Priangan produced more muscle than Javanese Fattailed rams. This conclusion also supported by Herman

Table 2. Carcass and non carcass components of Priangan and Javanese Fat-tailed rams (g)

\begin{tabular}{|c|c|c|c|c|c|c|}
\hline \multirow{2}{*}{ Parameters } & \multicolumn{3}{|c|}{ Slaughter weight (32.5 kg) } & \multicolumn{3}{|c|}{ Slaughter weight (40 kg) } \\
\hline & Priangan & JFT & Sig. & Priangan & JFT & Sig. \\
\hline Animals (heads) & $n=5$ & $n=6$ & & $n=6$ & $n=6$ & \\
\hline Slaughter Weight (g) & $32,460 \pm 55$ & $32,483 \pm 75$ & $\mathrm{~ns}$ & $36,708 \pm 3,088$ & $38,292 \pm 2,375$ & ns \\
\hline \multicolumn{7}{|l|}{ Inedible portion } \\
\hline Blood (g) & $1,291 \pm 162$ & $1,115 \pm 152$ & ns & $1,516 \pm 105$ & $1,367 \pm \quad 62$ & ns \\
\hline Gastric tract content $(\mathrm{g})$ & $3,121 \pm 350$ & $3,610 \pm 840$ & ns & $2,798 \pm 501$ & $3,007 \pm 718$ & ns \\
\hline \multicolumn{7}{|l|}{ Edible portion } \\
\hline Head (g) & $2,182 \pm 200$ & $1,718 \pm 155$ & $* *$ & $2,581 \pm 301$ & $1,809 \pm 189$ & $* *$ \\
\hline Skin (g) & $2,257 \pm 40$ & $2,198 \pm 137$ & ns & $2,783 \pm 395$ & $2,719 \pm 340$ & ns \\
\hline Carcass (g) & $17,380 \pm 228$ & $17,683 \pm 673$ & ns & $20,142 \pm 1,716$ & $21,258 \pm 967$ & ns \\
\hline Liver $(\mathrm{g})$ & $502 \pm 73$ & $588 \pm 55$ & * & $500 \pm \quad 77$ & $644 \pm 115$ & * \\
\hline Lymph (g) & $46 \pm 3$ & $40 \pm 9$ & ns & $54 \pm$ & $48 \pm$ & ns \\
\hline Lungs (g) & $310 \pm 28$ & $302 \pm 29$ & ns & $326 \pm \quad 33$ & $301 \pm \quad 34$ & ns \\
\hline Heart (g) & $119 \pm 8$ & $112 \pm \quad 7$ & ns & $134 \pm$ & $133 \pm \quad 15$ & ns \\
\hline Genitals (g) & $110 \pm 55$ & $54 \pm 10$ & ns & $45 \pm$ & $44 \pm$ & ns \\
\hline Testes (g) & $326 \pm 13$ & $216 \pm 22$ & ns & $333 \pm \quad 39$ & $225 \pm \quad 51$ & $* *$ \\
\hline Kidney (g) & $98 \pm 44$ & $78 \pm 14$ & ns & $88 \pm \quad 13$ & $103 \pm 31$ & ns \\
\hline Pancreas (g) & $44 \pm \quad 6$ & $53 \pm 17$ & ns & $47 \pm$ & $54 \pm$ & ns \\
\hline Stomach (g) & $798 \pm 117$ & $843 \pm 93$ & ns & $770 \pm 121$ & $855 \pm \quad 71$ & ns \\
\hline Small intestine (g) & $369 \pm 100$ & $458 \pm \quad 4$ & ns & $325 \pm \quad 94$ & $553 \pm 196$ & ns \\
\hline Large intestine (g) & $336 \pm 62$ & $317 \pm 26$ & ns & $525 \pm 100$ & $475 \pm \quad 88$ & ns \\
\hline Omental Fat (g) & $1,468 \pm 551$ & $1,009 \pm 288$ & ns & $2,066 \pm 385$ & $1,705 \pm 528$ & ns \\
\hline Tail (g) & $217 \pm 63$ & $1,041 \pm 203$ & $* *$ & $241 \pm 91$ & $1,081 \pm 125$ & ** \\
\hline Shank (g) & $723 \pm 9$ & $713 \pm 46$ & ns & $762 \pm \quad 74$ & $841 \pm \quad 80$ & ns \\
\hline Thorax Fat (g) & $53 \pm 26$ & $96 \pm 49$ & ns & $109 \pm \quad 30$ & $112 \pm \quad 26$ & ns \\
\hline
\end{tabular}

Note: JFT= Javanese Fat-tailed Sheep, Sig.= significance differ between breeds, ${ }^{* *}=$ very significant $(\mathrm{P}<0.01)$, ${ }^{*}=$ significant $(\mathrm{P}<0.05)$, ns= not significant $(\mathrm{P}>0.05)$. 
(2004) who mentioned that Priangan had heavier carcass muscle weight than others local breeds particularly in the neck and thorax parts. Priangan rams have masculine characteristics which traditionally are used as fighter animals contest. Masculinity is correlated to testosterone level in blood which is to be testicular hormone responsible for lean production (Zubir et al., 2011).

In contrast, fat tissue of Javanese Fat-tailed rams slaughtered at $40 \mathrm{~kg}$ was heavier than Priangan rams $(\mathrm{P}<0.05)$. This result indicated that Priangan rams were assumed to be less physiological mature than Javanese Fat-tailed sheep. Maturity of animals determines for increasing growth of fat instead of muscle. Priyanto \& Johnson (2012) reported the pattern differences of carcass fat were determined by cattle breeds. The differences of maturity type of sheep breeds might impact on pattern of fat deposition (McPhee et al., 2008). In general, total lean and bone decreased while total fat of carcass increased with increasing sheep weight (Abdullah \& Qudsieh, 2008). The same result was concluded by Herman (2001) that mentioned generally Javanese Fattailed Sheep had a higher fat tissue than Priangan sheep. Freking \& Leymaster (2004) also mentioned distribution of carcass fat was determined by sheep breeds.

\section{Non Carcass Components}

The weight and percentages of all non carcass component organs between Priangan and Javanese Fattailed rams at similar live weight were not significantly different $(P>0.05)$, except for the weight of head, liver and tail (Table 2). The tail of Javanese Fat-tailed sheep was heavier $(\mathrm{P}<0.01)$ due to the weight of the tail as fat deposits as its reported by Herman (2005). In contrast, head weight of Priangan was heavier due to their large horns $(\mathrm{P}<0.01)$. Djajanegara \& Rangkuti (1989) mentioned that Priangan rams have large curled horns. Weight of testes for Priangan sheep slaughtered at 40 $\mathrm{kg}$ weight was heavier compared to Javanese Fat-tailed sheep $(\mathrm{P}<0.01)$. Priangan rams were indicated have high level of blood testosterone which determine masculinity and testes size. The difference of liver and head weight also mentioned by Zgur et al. (2003) who used different sex of lambs, but in general their study did not result different significant of non carcass component.

In the present study, the contribution of total noncarcass components as a percentage of slaughter weigh represented between $44.8 \%-46.4 \%$, with no differences between breeds. Herman (2005) also concluded that there

Table 3. Carcass and non carcass components of Priangan and Javanese Fat-tailed rams (\% slaughter weight)

\begin{tabular}{|c|c|c|c|c|c|c|}
\hline \multirow{2}{*}{ Parameters } & \multicolumn{3}{|c|}{ Slaughter weight (32.5 kg) } & \multicolumn{3}{|c|}{ Slaughter weight (40 kg) } \\
\hline & Priangan & JFT & Sig. & Priangan & JFT & Sig. \\
\hline Animals (heads) & $n=5$ & $n=6$ & & $n=6$ & $n=6$ & \\
\hline \multicolumn{7}{|l|}{ Inedible portion } \\
\hline Blood (\%) & $3.97 \pm 0.50$ & $3.57 \pm 0.47$ & ns & $4.13 \pm 0.29$ & $3.72 \pm 0.24$ & ns \\
\hline Gastric tract content (\%) & $9.60 \pm 1.08$ & $11.11 \pm 2.59$ & ns & $7.65 \pm 1.36$ & $7.79 \pm 1.96$ & ns \\
\hline \multicolumn{7}{|l|}{ Edible portion } \\
\hline Head (\%) & $6.72 \pm 0.62$ & $5.29 \pm 0.17$ & ** & $7.03 \pm 0.63$ & $4.93 \pm 0.51$ & $* *$ \\
\hline Skin $(\%)$ & $6.95 \pm 0.12$ & $6.77 \pm 0.42$ & ns & $7.58 \pm 1.08$ & $7.41 \pm 0.93$ & ns \\
\hline Liver (\%) & $1.55 \pm 0.22$ & $1.81 \pm 0.17$ & * & $1.36 \pm 0.21$ & $1.68 \pm 0.24$ & * \\
\hline Lymph (\%) & $0.14 \pm 0.01$ & $0.12 \pm 0.03$ & ns & $0.15 \pm 0.02$ & $0.13 \pm 0.02$ & ns \\
\hline Lungs (\%) & $0.96 \pm 0.07$ & $0.93 \pm 0.09$ & ns & $0.89 \pm 0.09$ & $0.82 \pm 0.09$ & ns \\
\hline Heart $(\%)$ & $0.37 \pm 0.02$ & $0.37 \pm 0.02$ & ns & $0.37 \pm 0.02$ & $0.36 \pm 0.04$ & ns \\
\hline Genitals (\%) & $0.34 \pm 0.17$ & $0.17 \pm 0.03$ & ns & $0.12 \pm 0.02$ & $0.12 \pm 0.01$ & ns \\
\hline Testes (\%) & $1.00 \pm 0.04$ & $0.66 \pm 0.07$ & ns & $0.91 \pm 0.11$ & $0.61 \pm 0.14$ & $* *$ \\
\hline Kidney (\%) & $0.30 \pm 0.14$ & $0.24 \pm 0.04$ & ns & $0.24 \pm 0.04$ & $0.28 \pm 0.08$ & ns \\
\hline Pancreas (\%) & $0.14 \pm 0.02$ & $0.16 \pm 0.05$ & ns & $0.13 \pm 0.02$ & $0.15 \pm 0.02$ & ns \\
\hline Stomach (\%) & $2.46 \pm 0.36$ & $2.60 \pm 0.29$ & ns & $2.10 \pm 0.33$ & $2.23 \pm 0.19$ & ns \\
\hline Small intestine (\%) & $1.14 \pm 0.31$ & $1.40 \pm 0.01$ & ns & $0.89 \pm 0.26$ & $1.47 \pm 0.53$ & ns \\
\hline Large intestine $(\%)$ & $1.04 \pm 0.19$ & $0.98 \pm 0.08$ & ns & $1.43 \pm 0.27$ & $1.29 \pm 0.24$ & ns \\
\hline Omental fat (\%) & $4.52 \pm 1.69$ & $3.13 \pm 0.89$ & ns & $5.63 \pm 1.05$ & $4.64 \pm 1.44$ & ns \\
\hline Tail (\%) & $0.67 \pm 0.19$ & $3.20 \pm 0.62$ & $* *$ & $0.66 \pm 0.25$ & $2.94 \pm 0.34$ & $* *$ \\
\hline Shank (\%) & $2.23 \pm 0.03$ & $2.19 \pm 0.14$ & ns & $2.08 \pm 0.20$ & $2.29 \pm 0.22$ & ns \\
\hline Thorax fat (\%) & $0.20 \pm 0.08$ & $0.29 \pm 0.15$ & ns & $0.36 \pm 0.08$ & $0.31 \pm 0.07$ & ns \\
\hline
\end{tabular}

Note: JFT= Javanese Fat-tailed Sheep, Sig.= significance differ between breeds, ${ }^{* *}=$ very significant $(\mathrm{P}<0.01),{ }^{*}=$ significant $(\mathrm{P}<0.05), \mathrm{ns}=$ not significant $(\mathrm{P}>0.05)$. 
were no differences of total non carcass composition between local sheep breeds that ranged from 48\%-51\% of slaughter weight. Bonvillani et al. (2010) mentioned that generally different feed management did not affect non carcass percentage that ranged between $40 \%-43 \%$.

Table 3 shows that based on the percentage of non-carcass components, at $32.5 \mathrm{~kg}$ slaughter weight, Priangan ram produce $8.95 \%$ head and shank, 6.95\% skin, $14.79 \%$ offal, $3.97 \%$ blood and $9.60 \%$ gut content, while Javanese Fat-tailed ram produce $55.44 \%$ carcass, $7.48 \%$ head and shank, $6.77 \%$ skin, $16.03 \%$ offal, $3.57 \%$ blood and $11.11 \%$ gut content. At $40 \mathrm{~kg}$ slaughter weight, Priangan ram produce $9.11 \%$ head and shank, $7.58 \%$ skin, $15.15 \%$ offal, $4.13 \%$ blood and $7.65 \%$ gut content, while Javanese Fat-tailed ram produce $55.58 \%$ carcass, $7.22 \%$ head and shank, $7.41 \%$ skin, $17.25 \%$ offal, $3.72 \%$ blood and $7.79 \%$ gut content.

Total edible portion of non carcass of both ram breeds ranged from $30-32 \%$ of slaughter weight. The edible portion from offal and omental fat ranged from $11.7 \%-13.7 \%$, testes and genitalia ranged $0.7 \%-1.3 \%$. Meanwhile, total inedible portion ranged from $12 \%$ $15 \%$ of slaughter weight. Akhmadi et al. (2005) who conducted a trial of different feed on Javanese Thintailed sheep resulted percentage of non-carcass edible portion $16 \%$ of slaughter weight. The difference in the percentage value of non carcass edible portion could be caused by the amount of gastrointestinal contents of each animal.

\section{CONCLUSION}

Priangan and Javanese Fat-tailed rams slaughtered in mature live weight were different in the composition of muscle and fat tissue. Priangan was leaner and the tail was lighter than Javanese Fat-tailed rams, but the head and testes of Priangan were heavier than Javanese Fat-tailed rams. The edible and inedible portion of noncarcass ranged from $30 \%-32 \%$ and $12 \%-15 \%$ of slaughter weight, respectively.

\section{REFERENCES}

Abdullah, A. Y. \& R. I. Qudsieh. 2008. Carcass characteristics of Awassi ram lambs slaughtered at different weight. Lives. Sci. 117:165-175. http://dx.doi.org/10.1016/ j.livsci.2007.12.020

Akhmadi, D., E. Purbowati, \& R. Adiwinarti. 2005. Edible portion percentage of rams fed different levels of diet tofu byproduct. J. Indon.Trop.Anim.Agric. 30:248-253.

Bonvillani, A., F. Pena, G. de Gea, G. Gomez, A. Petryana, \& J. Perea. 2010. Carcass characteristics of Criollo Cordobés kid goats under an extensive management system: Effects of gender and live weight at slaughter. Meat Sci. 86:651659. http://dx.doi.org/10.1016/j.meatsci.2010.05.018

da Silva, A.S., D. A. Furtado, A. N. De Medeiros, R. G. Costa, M. F. Cezar, \& J. M. P. Filho. 2011. Characteristics of carcass and non-carcass components in feedlot native goats in the Brazilian semiarid region. R. Bras. Zootec. 40:18151821. http://dx.doi.org/10.1590/S1516-35982011000800027

DGLAH (Directorat General Livestock and Animal Health). 2011. Livestock and Animal Health Statistic. Ministry of Agriculture, Republic of Indonesia, Jakarta.

Djajanegara, A. \& M. Rangkuti. 1989. Sheep Production and Development in Indonesia. C. Devendra \& PS. Faylon (Eds.). Book Series No 80/19E9. International Development Res. Center, Los Banos. Philippines. pp. 126- 137.

Freking, B. A. \& K. A. Leymaster. 2004. Evaluation of Dorset, Finnsheep, Romanov, Texel and Montadale breeds of sheep: IV. Survival, growth and carcass traits of F1 lambs. J. Anim. Sci. 82: 144-153.

Herman, R. 2005. Produksi karkas dan non karkas domba Priangan dan Ekor Gemuk pada bobot potong 17,5 dan 25.0 Kg. Med. Pet. 28:8-12.

Herman, R. 2004. Carcass composition and muscle distribution of mature Priangan rams. J. Indon. Trop. Anim. Agric. 29:57-64.

Herman, R. 2001. Komposisi karkas domba Priangan dan Ekor Gemuk jantan muda yang dipotong pada bobot yang bereda. J. Pet. dan Lingk. 08: 49-56.

Karim, S. A., K. Porwal, S. Kumar, \& V. K. Singh. 2007. Carcass traits of Kheri lambs maintained on different system of feeding management. Meat Sci. 76: 395-401. http://dx.doi. org/10.1016/j.meatsci.2006.06.008

Lambe, N. R., E. A. Navajas, K. A. McLean, G. Simm, \& L. Bünger. 2007. Changes in carcass traits during growth in lambs of two contrasting breeds, measured using computer tomography. Lives. Sci. 107:37-52. http://dx.doi. org/10.1016/j.livsci.2006.09.001

McPhee, M. J., D. L. Hopkins, \& D. W. Pethick. 2008. Intramuscular fat levels in sheep muscle during growth. Aus. J. Exp. Agric. 48: 904-909. http://dx.doi.org/10.1071/EA08046

NRC (National Research Council). 1985. Nutrient requirements of sheep. 6 ed. National Academy, Washington, D.C.

Pena, F., T. Cano, V. Domenech, Ma. J. Alcalde, J. Martos, A. Garc' 1a-Martinez, M. Herrera, \& E. Rodero. 2005. Influence of sex, slaughter weight and carcass weight on "noncarcass" and carcass quality in segure na lambs. Small Rum. Res.: 247-254.

Priyanto, R. \& E. R. Johnson. 2012. The growth and distribution of carcass fat in fatening steer of diferent breeds. Med. Pet. 35: 45-48. http://dx.doi.org/10.5398/medpet.2012.35.1.45

Rianto E., E. Lindasari, \& E. Purbowati. 2006. Pertumbuhan dan komponen fisik karkas domba ekor tipis jantan yang mendapat dedak padi dengan aras berbeda. J. Prod. Ternak. 8: 28-33

Steel, R. G. D. \& J. H. Torrie. 1980. Prinsip dan Prosedur Statistika. Terjemahan: B. Sumantri. Gramedia Pustaka Utama, Jakarta.

Yilmaz, A., B. Ekiz, M. Ozcan, C. Kaptan, H. Hanoglu, I. Erdogan, \& O. Kocak. 2009. Carcass traits of improved and indigenous lamb breeds of North-Western Turkey under an intensive production system. Ital. J. Anim. Sci. 8:663-675.

Zgur, S., A. Cividini, D. Kompan, \& D. Birtie. 2003. The effect of live weight at slaughter and sex on lambs carcass traits and meat characteristics. Agric. Cons. Sci. 68:155-159

Zubir, R. Priyanto, E. Gurnadi, W. Manulu, \& H. M. Winugroho. 2011. Production and physical composition of Priangan male sheep carcass supplemented by Pasak Bumi peptide (Eurycoma longifolia Jack). JITV 16: 184-193 